\title{
Prediction of pork supply via the calculation of pig population based on population prediction model
}

\author{
Fan Zhang, Fulin Wang* \\ (College of Engineering, Northeast Agricultural University, Harbin 150030, China)
}

\begin{abstract}
Based on the perspective of pig population system prediction, and accorded to principle of pig months transfer, this paper refers to the modeling principle and method of discrete population quantity prediction model. Then the prediction model of pork supply is derived and established: Firstly, the recursive model of pig population system and estimation model of pork supply was established. Then this study estimated the sum of monthly mortality and culling rate of breeding sows. Furthermore, the method for new left gilts in each month and estimation of breeding sows at each month of age was established. Last, this research established the estimation method model of the initial state of pig population. On this basis, an example calculation is made to predict the monthly pork supply in Heilongjiang Province from January 2016 to March 2018 in the future. The results showed that the prediction model of pork supply based on the prediction of pig population system is an effective perspective to study the forecast of pork supply. In the prediction stage, the prediction accuracy of the number of slaughtered fattened hogs was $96.36 \%$ and $97.54 \%$, and the prediction accuracy of pork supply was $98.08 \%$ and $93.82 \%$. This study not only lay a theoretical foundation for further study on the balance between pork supply and demand, but also helps to guide pork producers and governments at all levels to make relevant production decisions and plans.
\end{abstract}

Keywords: pig population, breeding sow, pig production, pork supply prediction, population prediction model DOI: $10.25165 /$ j.jjabe.20201302.5303

Citation: Zhang F, Wang F L. Prediction of pork supply via the calculation of pig population based on population prediction model. Int J Agric \& Biol Eng, 2020; 13(2): 208-217.

\section{Introduction}

As the main source of animal food for urban and rural residents in China, pork plays an irreplaceable role in meeting the demand for animal products of urban and rural residents. Scientific prediction of pork supply is also the basis for effective management of pork prices. Therefore, it is of great significance to strengthen the prediction of the supply of pork in China, to guide the production, circulation and consumption of live pigs, to ensure the supply of pork market, stabilize the price of pork and develop the live pig industry.

According to the extant literature review, it is observed that there have been few studies on the hog price forecasting though a considerable body of forecasting research focused on agricultural commodity price. Usually, hog is considered as one of the most important agricultural commodities. Thus, some analysis and discussions about the existing agricultural commodity price forecasting approaches will help to provide some valuable suggestions on the hog price forecasting. Within this field of agricultural commodity price forecasting, there are roughly two categories, static prediction and dynamic prediction. In static prediction, based on the cobweb theory ${ }^{[1,2]}$, according to the historical data of agricultural products such as pork, pork supply, scholars screen out the causes (influencing factors) that affect the fluctuation of pork supply ${ }^{[3,4]}$, and find out the fluctuation of pork

Received date: 2019-07-22 Accepted date: 2020-02-06

Biographies: Fan Zhang, PhD, Lecturer, research interests: agricultural system engineering and agricultural science and technology innovation, Email: zhangfan871120@163.com.

*Corresponding author: Fulin Wang, PhD, Professor, research interests: agricultural system engineering. NO.600 Changjiang Street Xiangfang District, College of Engineering, Northeast Agricultural University, Harbin 150030, China. Tel: +86-451-55191462, Email: fulinwang1426@126.com. supply and price through theoretical analysis ${ }^{[5-8]}$. In dynamic prediction, scholars mainly use linear regression prediction and nonlinear prediction method to predict pork supply and price fluctuations. In the traditional linear regression prediction method, scholars use many traditional statistical techniques to use the historical data of pork supply at the end of each year to simulate the fluctuation law of pork supply and predict the amount of pork supply at the end of each year ${ }^{[9-29]}$. With the deepening of research, scholars believe that the change of pork price is similar to the nonlinear dynamic system ${ }^{[30]}$. The added flexibility of nonlinear methods opens the door to a huge number of possible pork supply curve variations. The prediction accuracy of the nonlinear artificial intelligence (AI) tools such as neural network is significantly higher than traditional linear regression prediction $\operatorname{method}^{[31]}$. However, this method is always used for short-term forecast such as 20 days ${ }^{[30,32]}$.

The above research has contributed greatly to the development of pork supply research. However, the existing research, theoretical analysis or model simulation, mostly finds the fluctuation law of pork supply in the past based on historical data, which lacks the disclosure of the change law of future pork supply. In addition, these methods can only predict the supply of pork at the end of each year in the future or predict the supply of pork in the short term. But the pork supply at every moment in the future such as the monthly pork supply is ineffective, or the forecast time is too short such as $20 \mathrm{~d}$, which leads and the reference value for decision making for pig farmers and pork producers is limited.

For the prediction of pork production, population prediction model (PPM) is a useful evolutionary approach that can explore good solutions for complex problems such as the prediction of pork supply. In fact, according to the population control theory, pork is produced by slaughter pigs, and slaughtered pigs are grown from 
new born piglets, growing finishing pigs to fattening pigs. While the new born piglets are bred by sows. Therefore, as long as the current quantity of breeding sows can be controlled, the amount of pork supply at a certain time in the future you can determined or predicted. Therefore, using the PPM theory, it is possible to solve the problem of too short a prediction time, and also to control and predict the supply of pigs at each moment. Thus, in this study, PPM is adopted to calculate the pig population in recursive model of pig population system for pork supply prediction.

The overall objective of this research was to propose a prediction method which is a mechanism model for predicting the supply of pig and pork based on PPM. Specific objectives implemented to accomplish the overall objective were to: design a method to establish a correlation model between the price of pork and the number of new left gilts; according to the existing statistical data and the growth characteristics of pigs, present the estimation methods of new left gilts and capable sows in each year, determine the initial state of the pig population.

\section{Model building}

The Model building is divided into three parts. The first part is the recursive model of pig population system. Through calculation of the pig population system, the number of slaughter pigs can be obtained, and then the model of relationship between slaughter pig and pork supply can be used to calculate the quantity of pork supply. The second part is the evaluation method for new left gilts and breeding sows. This study researched this part from three aspects. Firstly, the sum of monthly mortality and culling rate of breeding sows was estimated. After calculating the sum of monthly mortality and culling rate of breeding sows, the estimate method for new left gilts in each month was built. For the estimation of new left gilts in each month, we must first establish the construction of the relationship model between new left gilts and pork prices, derive it through the formula, and bring in the value of sum of monthly mortality and culling rate of breeding sows to calculate the parameter estimation of the relationship model between new left gilts and pork prices. Finally, the first two aspects are combined to obtain a model of Evaluation of breeding sows at each month of age. The third part is the estimate of the initial condition of the pig population. In summary, these three parts can finally realize the prediction of pork supply. The flow diagram is shown in Figure 1.

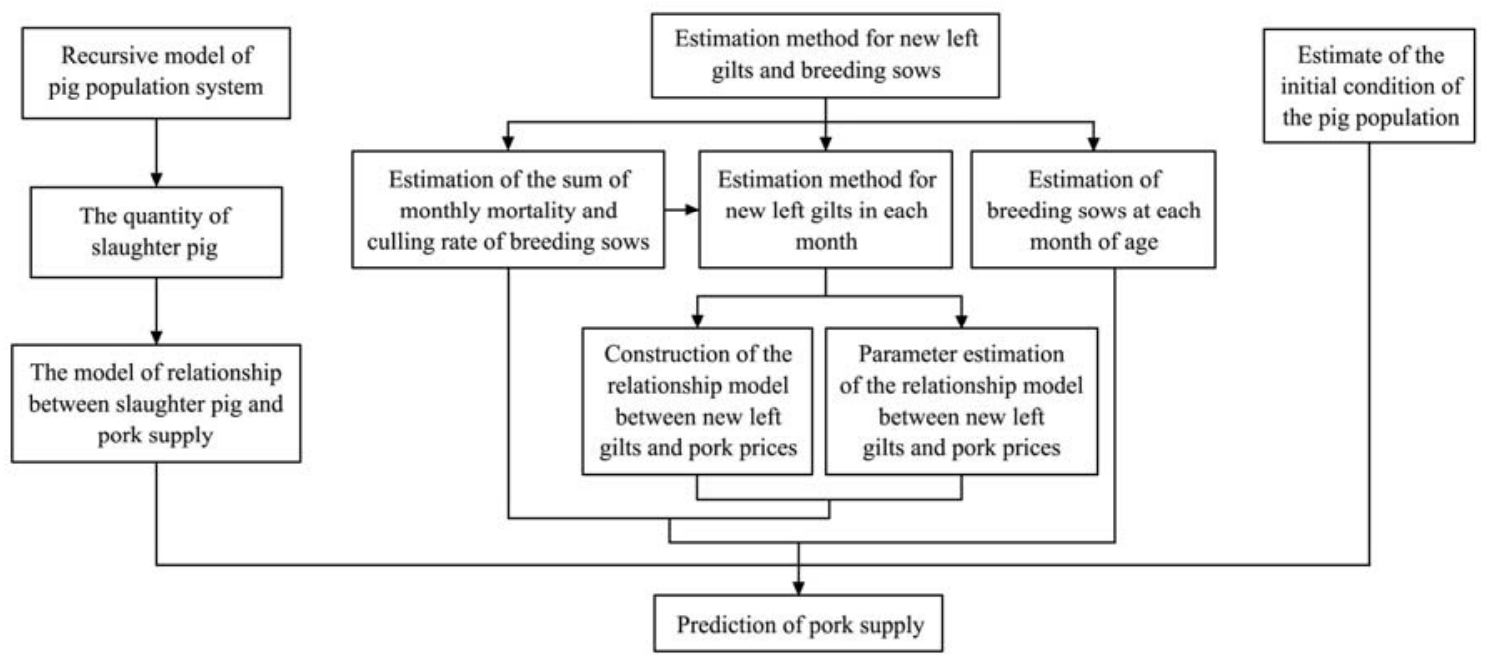

Figure 1 The flow diagram

\subsection{Derivation and establishment of the recursive model of pig population system and estimation model of pork supply \\ 2.1.1 Recursive model of pig population system}

At the time $t$ of a certain month in a certain place, the total number of sows whose ages are full of $r$ months but less than $r+1$ months is $r, r$ is an integer. Among them, the age range of breeding sow is $\left[r_{1}, r_{2}\right]$, the minimum age of breed sows is $r_{1}=12$, and the maximum age of breed sows is $r_{2}=54$.

If the number of pigs in a certain month is counted by month, that is, the total number of sows that are $r$ months old but less than $r+1$ months old at time $t$ is $z_{r}^{w}(t), r$ is equal to the integers $1,2,3 \ldots$ Among them, the month age interval of the breeding sows is $\left[r_{1}\right.$, $r_{2}$ ], the minimum age of $r_{1}$ that can be used for sows is generally 12 , and the maximum age of $r_{2}$ is generally 54. This is because the regulations of the statistical yearbook are used in this article, and the breeding sow is defined as sows who have given birth to one gilt and can continue to reproduce normally. When $f_{r}(t)$ is the number of piglets produced by the sows, the average number of pigs per year can be produced in one month at the time $t$ and $r$ months old, and $F$ is the total number of piglets that can be produced by the sows at the time of $t$ and $r$ months old.

$$
F_{r}(t)=f_{r}(t) \cdot z_{r}^{w}(t)
$$

If $r$ changes from $r_{1}$ to $r_{2}$, sum $F_{r}(t)$, and the total number of piglets that can be bred by all the sows at time $t$ is $z_{00}(t)$.

$$
z_{00}(t)=\sum_{r=\eta}^{r_{2}} f_{r}(t) z_{r}^{w}(t)
$$

When

$$
\begin{aligned}
& h_{r}(t)=\frac{f_{r}(t)}{\sum_{r=n}^{r_{2}} f_{r}(t)} \\
& \lambda(t)=\frac{\sum_{r=n}^{r_{2}} f_{r}(t)}{A}
\end{aligned}
$$

where, $h_{r}(t)$ is the breeding mode of breeding sows; $\lambda(t)$ indicates the total number of litters per breeding sow in the entire breeding interval at month $t ; A$ is the number of piglets per litter, then gets the result.

$$
\begin{gathered}
f_{r}(t)=A \cdot \lambda(t) \cdot h_{r}(t) \\
z_{00}(t)=A \cdot \lambda(t) \cdot \sum_{r=\eta_{1}}^{r_{2}} h_{r}(t) z_{r}^{w}(t)
\end{gathered}
$$

Then, the number of piglets $z_{0}(t)$ less than one month old in the new born piglets and the number of piglets $z_{1}(t+1)$ between the 1 month old and 2 months old at time $t$ are as follows:

$$
\begin{gathered}
z_{0}(t)=\left(1-d_{00}\right) z_{00}(t) \\
z_{1}^{w}(t+1)=\left(1-d_{0}\right) z_{0}(t)
\end{gathered}
$$


where, $d_{00}$ is the mortality rate of new born piglets; and $d_{0}$ is the mortality rate of new born piglets less than 1 month old.

When the new born piglets grow to the age between the 1 month old and 2 months old, they will be classified into three types by producers: boars, sows and finishing pigs according to their production functions. Among them, the sows left by the producers to breed piglets are called new left gilts. Thus let the total number of pigs growing from new born piglets to 1 month old at time $t$ is $z_{1}(t)$ and the number of new left gilts selected from 1 month old piglets at time $t$ is $z_{1}^{w}(t)$. Then at the time $t$ the number of new left boars at the age of 1 month and the number of young finishing pigs at the age of 1 month are as follows:

$$
\begin{gathered}
z_{1}^{w}(t)=k z_{1}^{M}(t) \\
z_{1}^{R}(t)=z_{1}(t)-z_{1}^{w}(t)-z_{1}^{M}(t)
\end{gathered}
$$

where, $k$ is the ratio of the number of sows to boars selected for piglets of one month old.

Recursively, at the age of 1 month the number of sows, boars and hog at $r+1$ month of age are as follows:

$$
\begin{array}{cc}
z_{r+1}^{w}(t+1)=\left(1-d_{r}^{w}\right) z_{r}^{w}(t) & r=2, \ldots, r_{2}-1 \\
z_{r+1}^{M}(t+1)=\left(1-d_{r}^{M}\right) z_{r}^{M}(t) & r=2, \ldots, r_{3}-1 \\
z_{r+1}^{R}(t+1)=\left(1-d_{r}^{R}\right) z_{r}^{R}(t) & r=2, \ldots, r_{\mathrm{r}}-1
\end{array}
$$

where, $z_{r}^{w}(t)$ is the number of $r$ month of age sows at time $t ; z_{r}^{M}(t)$ is the number of $r$ month of age boars at time $t ; z_{r}^{R}(t)$ is the number of $r$ month of age finishing pigs at time $t ; d_{r}^{w}$ is the mortality rate of $r$ month of age sows; $d_{r}^{M}$ is the mortality rate of $r$ month of age boars; $d_{r}^{R}$ is the mortality rate of $r$ month of age finishing pigs; $r_{3}$ is the maximum month of age for mating with boars; $r_{4}$ is the average month of age of pork pigs.

The above model is a recursive model that can be recursed to any subsequent month. In fact, the pig population is a process of constant transfer. In addition, in the basic idea of PPM, predictions can also be divided into purely natural predictions and predictions with disturbances. The so-called disturbances here mainly refer to mechanical changes, such as the possible future wars or natural disasters such as African swine fever, which disturb the development process of the pig population. This disturbance has great contingency and randomness. Therefore, we set a random disturbance term to represent such mechanical changes ${ }^{[33]}$.

In summary, the formulas for recursive by category and number of month of age pigs are:

(1) The recurrence formula of the distribution of the number of new born piglets by month of age is as follows:

$$
\begin{gathered}
z_{00}(t)=A \lambda(t) \sum_{r=n}^{r_{2}} h_{r}(t) z_{r}^{w}(t) \\
z_{0}(t)=\left(1-d_{00}\right) z_{00}(t) \\
z_{1}(t+1)=\left(1-d_{0}\right) z_{0}(t+1)
\end{gathered}
$$

(2) The recurrence formula for the distribution of sows by month of age is as follows, $z_{1}^{w}(t+1)$ is the number of artificially retained:

$$
\begin{gathered}
z_{2}^{w}(t+1)=\left(1-d_{1}^{w}\right) z_{1}^{w}(t)+x_{1}(t) \\
\ldots \\
z_{r+1}^{w}(t+1)=\left(1-d_{r}^{w}\right) z_{r}^{w}(t)+x_{r}(t)
\end{gathered}
$$

When the sows grow to 12 months of age, it becomes a breeding sows. The number of breeding sows is $z_{12}^{w}(t)$.

(3) The recurrence formula for the distribution of boars by month of age is as follows:

$$
z_{1}^{M}(t+1)=z_{1}^{w}(t+1) / k
$$

$$
\begin{gathered}
z_{2}^{M}(t+1)=\left[1-d_{1}^{M}\right] z_{1}^{M}(t)+x_{1}(t) \\
\cdots \\
z_{r+1}^{M}(t+1)=\left[1-d_{r}^{M}\right] z_{r}^{M}(t)+x_{r}(t)
\end{gathered}
$$

(4) The recurrence formula for the distribution of the number of pork pigs per month of age is as follows:

$$
\begin{gathered}
z_{1}^{R}(t+1)=z_{1}(t+1)-z_{1}^{W}(t+1)-z_{1}^{M}(t+1) \\
z_{2}^{R}(t+1)=\left[1-d_{1}^{R}\right] z_{1}^{R}(t)+x_{1}(t) \\
\cdots \\
z_{r+1}^{R}(t+1)=\left[1-d_{r}^{R}\right] z_{r}^{R}(t)+x_{r}(t)
\end{gathered}
$$

When the finishing pigs grow to 6 months of age, it becomes a slaughter pig, that is $z_{6}^{R}(t)$.

2.1.2 The model of relationship between slaughter pig and pork supply

If the meat production of a slaughter pig is $\mathrm{CR}$, and the number of slaughter at t time is $z_{6}^{R}(t)$, then the pork quantity $Z^{R}(t)$ at $t$ time is:

$$
Z^{R}(t)=C R \cdot z_{6}^{R}(t)
$$

\subsection{Estimation method for new left gilts and breeding sows}

2.2.1 Estimation of the sum of monthly mortality and culling rate of breeding sows

There are not only natural mortality rates, but also artificial elimination rates for breeding sows. Let $D_{N}^{W}$ indicates the sum of the maternal mortality and culling rate per year, $d_{N}^{W}$ indicates the mortality rate of the annual breeding sows, $D_{N}^{W}$ indicates the elimination rate of the annual breeding sows; $D_{r}^{W}$ indicates the sum of mortality and elimination rate of $r$ month of age breeding sows; $d_{r}^{W}$ indicates the mortality rate of breeding sows $d_{N}^{W}$ indicates the elimination rate of $r$ month of age breeding sows. Then $D_{N}^{W}$ and $D_{r}^{W}$ are as follows:

$$
\begin{gathered}
D_{N}^{W}=d_{N}^{W}+d_{N}^{W}, \\
D_{r}^{W}=d_{r}^{W}+d_{r}^{W},
\end{gathered}
$$

In the current study, there are only statistical data on the sum of annual mortality and elimination rate of breeding sows, but there's no statistical data on the sum of monthly mortality and elimination rate for breeding sows. The sum of monthly mortality and elimination rate of breeding sows is the basis of subsequent estimation method for new left gilts. Therefore, this study tries to establish the relationship between the sum of mortality and elimination rate of breeding sows per year $\left(D_{N}^{W}\right)$ and the sum of mortality and elimination rate of monthly breeding sows $\left(D_{r}^{W}\right)$. Then the sum of mortality and elimination rate of breeding sows can be determined each month.

Based on the statistical methods of population mortality, the estimated value $D_{N}^{W_{1}}$ of annual mortality and elimination rate of breeding sows is the ratio of the number of breeding sows dead and eliminated in one year to the number of breeding sows dead and eliminated in the middle of the same period, expressed by the percentage of 1000, as shown in Equation (21). It should be noted in particular that the breeding sows are eliminated immediately when they reach the age of 54 months, that is, the total number of breeding sows that the breeding sows whose age is 54 months are not included in the total number of breeding sows in $t$ month. While the number of breeding sows eliminated and dead in $t$ month included the number of breeding sows eliminated at 53 months of age in $t-1$ month and the number of breeding sows that were eliminated after the $t$ month grew to 54 months of age. As shown in the following formula: 


$$
\begin{gathered}
\sum_{t=1}^{12} z_{12}^{w}(T, t) \cdot D_{r}^{w}\left[1+\left(1-D_{r}^{w}\right)+\left(1-D_{r}^{w}\right)^{2}+\ldots\left(1-D_{r}^{w}\right)^{12-t}\right]+\sum_{r=13}^{42} \sum_{n=0}^{11} z_{r}^{w}(T, 1) \cdot D_{r}^{w}\left(1-D_{r}^{w}\right)^{n}+ \\
D_{N}^{W^{\prime}}=\frac{\sum_{r=43}^{53} z_{r}^{w}(T, 1) \cdot D_{N}^{w}\left[1+\left(1-D_{r}^{w}\right)+\left(1-D_{r}^{w}\right)^{2}+\ldots+\left(1-D_{r}^{w}\right)^{53-r}\right]+\sum_{r=43}^{54} z_{r}^{w}(T, 1) \cdot\left(1-D_{r}^{w}\right)^{54-r}}{\frac{1}{2} \cdot \sum_{r=12}^{54}\left[z_{r}^{w}(T-1)+z_{r}^{w}(T)\right]}
\end{gathered}
$$

where, $z_{r}^{R}(T, 1)$ represents the number of breeding sows in the month of January at $r$ month of age in $T$ year. The first item indicates the number of eliminated breeding sows at the 12 months of age per month from January to December in $T$-year, the fourth item indicates the total number of breeding sows that have reached the age of 54 months. Among them, the number of breeding sows at 12 months is as follow:

$$
\begin{aligned}
Z_{12}^{W}(t)= & Z_{1}^{W}(t-11)\left(1-D_{1}^{W}\right)\left(1-D_{2}^{W}\right)\left(1-D_{3}^{W}\right)\left(1-D_{4}^{W}\right)\left(1-D_{5}^{W}\right) \\
& \left(1-D_{6}^{W}\right)\left(1-D_{7}^{W}\right)\left(1-D_{8}^{W}\right)\left(1-D_{9}^{W}\right)\left(1-D_{10}^{W}\right)\left(1-D_{11}^{W}\right)
\end{aligned}
$$

where, $D_{r}^{w}(r=1,2,3, \ldots, 11)$ is the sum of the mortality and elimination rate of the non-breeding sow at $r$ months. In summary, taking the minimum absolute error between the actual value and the estimated value of annual mortality and elimination rate as the goal, that is $\min \left|D_{N}^{W}-D_{N}^{W^{\prime}}\right|$, we constructed a model for calculating the sum of mortality and elimination rate of monthly breeding sows. According to expert consultation, the sum of the annual mortality rate and the elimination rate of the breeding sows can be $40 \%$. Assuming that the newly kept gilts in each month are a fixed value $Z_{1}^{W}(t)$, and under the condition of $\min \left|40 \%-D_{N}^{W^{\prime}}\right|, \quad D_{r}^{W}=0.01735$ can be obtained.

2.2.2 Estimation method for new left gilts in each month

(1) Construction of the relationship model between new left gilts and pork prices

In production practice, pork production often depends on the producer's response to price ${ }^{[33]}$. Therefore, when the price of pork rises, the producers will increase their enthusiasm for breeding pigs, and keep more sows for breeding piglets. We call the sows which people kept for breeding piglets. Then the number of pigs which they breed will increase, and the economic returns of the output of pork will increase too. However, when the price of pork rises falls, the producer's enthusiasm for breeding is weakened. And then the producer will keep fewer sows. So the breeding of the piglets will be reduced accordingly. Since there is still a lack of research on the influencing factors and estimation methods of new gilts, this paper is an initial exploration of the factors affecting the number of new left gilts. This study attempts to select the most direct factor affecting the new left gilts - pork prices, and establishes a relationship model between pork prices and new left gilts. In summary, this research proposes the hypothesis that the quantity of new left gilts grows with the price of pork:

$$
z_{1}^{W}(T, t)=a+b \cdot P(T, t)
$$

In Equation (23), it refers to the number of new left gilts in the first month of the year (that is, the 1-month-old gilts that are kept in the new born piglets in each month of the year), which is the pork price in the first year of the month. And in Equation (23), all variables are unknown except pork prices. Therefore, how to estimate the parameter $a$ and $b$ in Equation (23) is a problem that needs to be solved.

(2) Parameter estimation of the relationship model between new left gilts and pork prices

Due to the lack of statistical data on new left gilts, the values of parameters $a$ and $b$ in Equation (23) cannot be calculated by linear regression. This research tries to solve this problem through other ideas which is to establish a relationship model between the breeding sow and the new left gilts, and to bring the relationship formula between the new left gilts and the price of pork into this relationship model. The basis for this is the breeding sows are grown by the new left gilts, and there's a quantitative relationship between them. Data on the amount of breeding sows each year and the pork price data can both be obtained. In this way, parameters $a$ and $b$ in the model of the relationship between the new gilts and pork prices can be estimated.

The current statistics on the number of stocks of breeding sows per year are counted from the end of the year. Therefore, this paper establishes the relationship between the number of breeding sows at the end of $T+1$ year. The formula mainly includes three items: The first item is the number of breeding sows that can experience death and elimination in the $T$ year and grow to the end of the $T+1$ year; The second item is that the new left gilts in $T+1$ in January will experience 11 months. According to their monthly mortality and elimination rate, they will grow to 12 months of age at the end of $T+1$ and join the breeding sows. The third item is that the new left gilts from February to December in $T$-year will become breeding sows in the next year, according to their monthly mortality and elimination rates. According to the above relationship, the number of breeding sows $Z_{N}^{W}(T+1)$ at the end of the $T+1$ year can be estimated as follows:

$$
\begin{aligned}
Z_{N}^{W}(T+1)= & Z_{N}^{w}(T) \cdot\left(1-D_{N}^{w}\right)+\sum_{t=2}^{12} Z_{1}^{w}(T, t) \cdot \prod_{r=1}^{24-t}\left(1-D_{r}^{w}\right)+ \\
& Z_{r}^{w}(T+1,1) \cdot \prod_{r=1}^{11}\left(1-D_{r}^{w}\right)
\end{aligned}
$$

Bring the Equation (23) into the Equation (24), and finishing:

$$
\begin{aligned}
& \frac{Z_{N}^{W}(T+1)-Z_{N}^{W}(T) \cdot\left(1-D_{N}^{W}\right)}{\prod_{r=1}^{11}\left(1-D_{r}^{w}\right)+\sum_{t=2}^{12} \prod_{r=1}^{24-t}\left(1-D_{r}^{w}\right)}=a+ \\
& \frac{\sum_{t=2}^{12} p(T, t) \cdot \prod_{r=1}^{24-t}\left(1-D_{r}^{w}\right)+p(T+1,1) \cdot \prod_{r=1}^{11}\left(1-D_{r}^{w}\right)}{\prod_{r=1}^{11}\left(1-D_{r}^{w}\right)+\sum_{t=2}^{12} \prod_{r=1}^{24-t}\left(1-D_{r}^{w}\right)} \cdot b
\end{aligned}
$$

When:

$$
\begin{gathered}
y(T)=\frac{Z_{N}^{W}-Z_{N}^{W}(T) \cdot\left(1-D_{N}^{W}\right)}{\prod_{r=1}^{11}\left(1-D_{r}^{W}\right)+\sum_{t=2}^{12} \prod_{r=1}^{24-t}\left(1-D_{r}^{W}\right)}, \\
x(T)=\frac{\sum_{t=2}^{12} p(t, T) \cdot \prod_{r=1}^{24-t}\left(1-D_{r}^{W}\right)+p(1, T+1) \cdot \prod_{r=1}^{11}\left(1-D_{r}^{W}\right)}{\prod_{r=1}^{11}\left(1-D_{r}^{W}\right)+\sum_{t=2}^{12} \prod_{r=1}^{24-t}\left(1-D_{r}^{W}\right)}
\end{gathered}
$$

Then the formula can be written as follow:

$$
y(T)=a+b x(T) \quad T=1,2, \ldots, n
$$

If the estimated value of $y(T)$ is recorded as $\hat{y}(T), \hat{y}(T)=$ $a+b x(T)$. Let $Q=\sum_{T=1}^{n}(y(T)-\hat{y}(T))^{2}$. According to the principle of least squares, we can obtain the result as follow:

$$
\left\{\begin{array}{c}
a=\frac{\sum_{T=1}^{n} x(T)^{2} \sum_{T=1}^{n} y(T)-\sum_{T=1}^{n} x(T) \sum_{T=1}^{n} y(T) x(T)}{n \sum_{T=1}^{n} x(T)^{2}-\left(\sum_{T=1}^{n} x(T)\right)^{2}} \\
b=\frac{n \sum_{T=1}^{n} y(T) x(T)-\sum_{T=1}^{n} y(T) \sum_{T=1}^{n} x(T)}{n \sum_{T=1}^{n} x(T)^{2}-\left(\sum_{T=1}^{n} x(T)\right)^{2}} \\
T=1,2, \ldots n
\end{array}\right.
$$

2.2.3 Estimation of breeding sows at each month of age

In summary, the estimated models for the breeding sows at each month of age are as follow: 


$$
\begin{gathered}
z_{12}^{w}(t)=z_{1}^{w}(t-11) \prod_{r=1}^{11}\left(1-D_{r}^{W}\right)=z_{1}^{w}(t-11)\left(1-D_{1}^{W}\right)\left(1-D_{2}^{W}\right) \ldots\left(1-D_{11}^{W}\right) \\
\vdots \\
z_{54}^{w}(t)=z_{1}^{w}(t-53) \prod_{r=1}^{53}\left(1-D_{r}^{W}\right)=z_{1}^{w}(t-53)\left(1-D_{1}^{W}\right)\left(1-D_{2}^{W}\right) \ldots\left(1-D_{53}^{W}\right)
\end{gathered}
$$

\subsection{Estimate of the initial condition of the pig population}

The initial state of the pig population is the basic data for the prediction of pork supply and is also a prerequisite for prediction. In order to predict the pork supply, it is necessary to obtain the basic data of the initial state of the population, but there is no annual statistics for these data. Therefore, the initial state of the pig population needs to be estimated. The initial status of the pig population includes new born piglets, sow populations, boar populations and porker populations. All kinds of pigs are recursed monthly according to their monthly mortality. New born piglets which are bred by breeding sows are added to the pig populations each month. The above estimates the number of breeding sows per month by establishing a monthly estimation model. Therefore, if the base month is $t$ month, the initial state of the new born piglet in $\mathrm{t}$ month is as follow:

$$
\begin{gathered}
z_{00}(t)=A \cdot \lambda(t) \cdot \sum_{r=n}^{r_{2}} h_{r}(t) z_{r}^{w}(t) \\
z_{0}(t)=\left(1-d_{00}\right) z_{00}(t) \\
z_{1}(t)=\left(1-d_{0}\right) z_{0}(t-1)
\end{gathered}
$$

The above estimates the number of new left gilts in each month by establishing a monthly estimation model. According to the transfer principle of the pigs by the age of the month, the distribution of the number of sows per month can be estimated. Then the initial state of the sow population in $t$ months is as follow:

$$
\begin{gathered}
z_{1}^{w}(T, t)=a+b \cdot P(T, t) \\
z_{2}^{w}(T, t)=z_{1}^{w}(t-1)\left(1-D_{1}^{W}\right) \\
\vdots \\
z_{54}^{w}(T, t)=z_{1}^{w}(t-53)\left(1-D_{1}^{w}\right)\left(1-D_{2}^{w}\right) \ldots\left(1-D_{11}^{W}\right)\left(1-D_{N}^{W}\right)^{43}
\end{gathered}
$$

The proportion of producers who keep boars and sows is $k$. Therefore, the initial state of the boar populations is as follow:

$$
\begin{gathered}
z_{1}^{M}(t)=z_{1}^{W}(t) / k \\
z_{2}^{M}(T, t)=z_{1}^{w}(t-1)\left(1-D_{1}^{W}\right) / k
\end{gathered}
$$

$$
z_{54}^{M}(T, t)=z_{1}^{w}(t-53)\left(1-D_{1}^{W}\right)\left(1-D_{2}^{w}\right) \ldots\left(1-D_{11}^{W}\right)\left(1-D_{r}^{W}\right)^{43} / k
$$

The breeding pigs can breed new born piglets. After the new born piglets grow to 1 month of age, the producers decide the number of new left gilts who are left according to the current pork price, and choose the new left boars for breeding, and the rest are used as finishing pigs who will be slaughtered after 6 months of age. Therefore, the initial state of the porker population is as follow:

$$
\begin{aligned}
& z_{c}^{R}(t)= {\left[\left(A \lambda(t-6) \sum_{r=n}^{\prime 2} h_{r}(t-6) z_{r}^{w}(t-6)\right)\left(1-d_{00}\right)\left(1-d_{0}\right)-\right.} \\
&\left.z_{1}^{w}(t-5)-\frac{z_{1}^{w}(t-5)}{k}\right] \cdot\left(1-d_{1}\right)\left(1-d_{2}\right)\left(1-d_{3}\right)\left(1-d_{4}\right)\left(1-d_{5}\right) \\
& z_{5}^{R}(t)=\left[\left(A \lambda(t-5) \sum_{r=n}^{r_{2}} h_{r}(t-5) z_{r}^{w}(t-5)\right)\left(1-d_{00}\right)\left(1-d_{0}\right)-\right. \\
&\left.z_{1}^{w}(t-4)-\frac{z_{1}^{w}(t-4)}{k}\right] \cdot\left(1-d_{1}\right)\left(1-d_{2}\right)\left(1-d_{3}\right)\left(1-d_{4}\right) \\
& z_{4}^{R}(t)=\left[\left(A \lambda(t-4) \sum_{r=n}^{r_{2}} h_{r}(t-4) z_{r}^{w}(t-4)\right)\left(1-d_{00}\right)\left(1-d_{0}\right)-\right. \\
&\left.z_{1}^{w}(t-3)-\frac{z_{1}^{w}(t-3)}{k}\right] \cdot\left(1-d_{1}\right)\left(1-d_{2}\right)\left(1-d_{3}\right)
\end{aligned}
$$

$$
\begin{aligned}
z_{3}^{R}(t)= & {\left[\left(A \lambda(t-3) \sum_{r=n}^{n_{2}} h_{r}(t-3) z_{r}^{w}(t-3)\right)\left(1-d_{00}\right)\left(1-d_{0}\right)-\right.} \\
& \left.z_{1}^{w}(t-2)-\frac{z_{1}^{w}(t-2)}{k}\right] \cdot\left(1-d_{1}\right)\left(1-d_{2}\right) \\
z_{2}^{R}(t)= & {\left[\left(A \lambda(t-2) \sum_{r=n}^{r_{2}} h_{r}(t-2) z_{r}^{w}(t-2)\right)\left(1-d_{00}\right)\left(1-d_{0}\right)-\right.} \\
& \left.z_{1}^{w}(t-1)-\frac{z_{1}^{w}(t-1)}{k}\right] \cdot\left(1-d_{1}\right) \\
z_{1}^{R}(t)= & \left(A \lambda(t-1) \sum_{r=n}^{h_{2}} h_{r}(t-1) z_{r}^{w}(t-1)\right)\left(1-d_{00}\right)\left(1-d_{0}\right)- \\
& z_{1}^{w}(t)-\frac{z_{1}^{w}(t)}{k}
\end{aligned}
$$

\section{Example calculations}

At present, only annual data of pork supply before 2018 (including 2018) can be derived. And this actual data can verify whether the prediction results in this paper are accurate. Therefore, in the section of example calculation, based on the above-mentioned pork supply forecasting mode and the relevant data from 2000 to 2015 , this study mainly predict the number of pig population and pork supply in each month of Heilongjiang Province in China from 2016 to 2018. It should be specially stated that the random disturbances such as war or natural disasters have great contingency. In the theory of PPM, these random disturbances are difficult to predict, and the pure natural variation prediction of the pig population is the main part of the prediction. Therefore, in the example calculation, the random disturbance is ignored. We set $x_{i}(t)=0$.

\subsection{Data source and description}

The data of the number of breeding sows and the number of pigs in Heilongjiang Province in China from the end of 2000-2015 are all taken from China Animal Husbandry and Veterinary Yearbook. The pork price data of Heilongjiang Province from 2000 to 2015 is taken from China Animal Husbandry Information Network.

\subsection{Determination of model parameters}

The following four parameters are determined from the statistical yearbook or expert consultation. The parameters consulted by experts are without official standard statistics. Therefore, this research summarized the opinions of the experts by the method of expert survey. And finally, we get the parameter values of each parameter. The experts consulted mainly include the famous animal husbandry experts such as Wang Xibiao's team and Li Yanhua's team.

\subsubsection{Sum of mortality and elimination rates}

According to the methods of accessing statistical yearbooks, combined with the above estimation methods for the sum of mortality and elimination rates of breeding sows and boars. The sum of the mortality and elimination rates for each category of pigs is shown in Figure 2.

\subsubsection{How many litters per year and litter interval}

According to the expert consultation and the survey of farmers, a breeding sow can produce about 2 litters a year. Calculated from the completion of the breeding sows, after nursing, returning to breeding, breeding, pregnancy, until piglet again, this is the interval between the litters of breeding sows per litter, about 6 months.

\subsubsection{Average meat production of slaughter pig}

According to expert consultation, the average meat production of slaughter pig in Heilongjiang Province is $78 \mathrm{~kg} / \mathrm{head}$, which is $\mathrm{CR}=78$. 


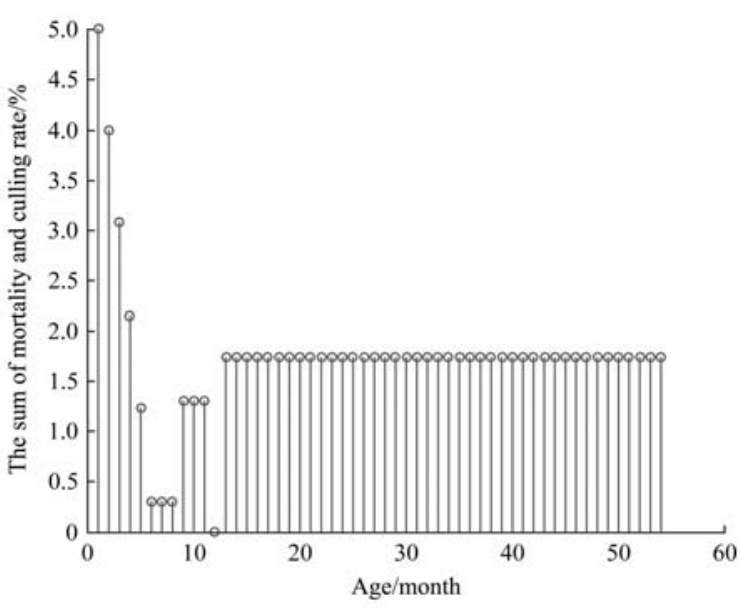

Figure 2 Sum of mortality and elimination rate of each month of age sows

\subsubsection{Ratio of sows to boars}

According to expert consultation and data inquiry ${ }^{[34]}$, it is generally known that a breeding boar can equal the breeding task of 20 breeding sows. Therefore, the ratio of sows to boars is $20: 1$, then $k=20$.

\subsection{Examples and results evaluation}

\subsubsection{Estimation of new left gilts and breeding sows}

We bring pork prices from January 2000 to December 2015 in Heilongjiang Province, the numbers of annual breeding sows and the sum of the annual mortality and elimination rates of breeding sows into the relationship model between new left gilts and pork prices. Then we can get 16 sets of values about $x(T)$ and $y(T)$. And the relationship model between the new left gilts and pork prices is obtained by using the principle of least squares to solve the parameters in the model.

$$
Y=0.092791 x+4.3907
$$

The effect of regression analysis is shown in Figure 3. The residual plot is shown in Figure 4. It can be seen from the residual graph that the residuals are random and the residuals do not show a certain trend. It indicates that the sample data is normal.

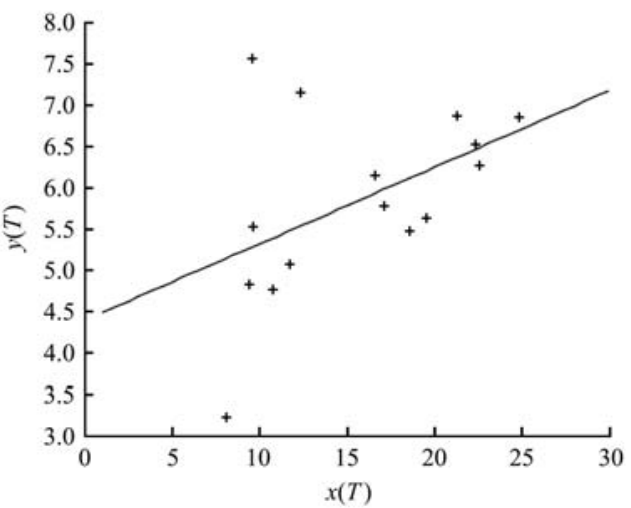

Figure 3 Regression analysis graph of $x(T)$ and $y(T)$

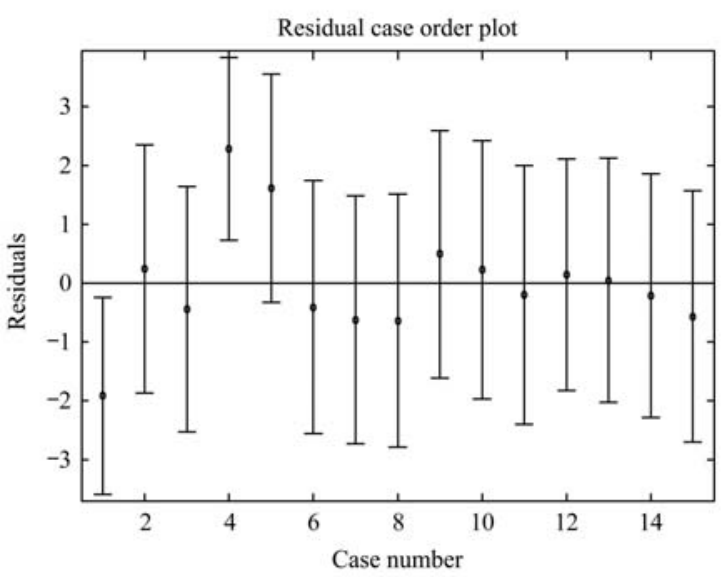

Figure 4 Plot of residuals

The regression equation was tested for fitness. The correlation coefficient of the regression equation was $R=0.47528$, and $p$-value $<0.1$

The data which is the price of pork from January 2000 to December 2014 in Heilongjiang Province will be brought into the one-way regression model in Equation (44). And the quantities of new left gilts from 2000 to 2015 in Heilongiiang Province will be calculated in Table 1 below.

Table 1 Estimated value of new left gilts from 2000 to 2015

\begin{tabular}{|c|c|c|c|c|c|c|c|c|c|c|c|c|}
\hline & $\begin{array}{c}\text { January } \\
\text { ten thousand }\end{array}$ & $\begin{array}{l}\text { February } \\
\end{array}$ & March & April & May & June & July & August & September & October & November & December \\
\hline 2000 & 5.10 & 5.04 & 4.99 & 5.10 & 5.07 & 5.08 & 5.13 & 5.26 & 5.24 & 5.17 & 5.13 & 5.23 \\
\hline 2001 & 5.23 & 5.27 & 5.27 & 5.32 & 5.32 & 5.23 & 5.23 & 5.27 & 5.30 & 5.32 & 5.31 & 5.32 \\
\hline$\vdots$ & $\vdots$ & $\vdots$ & $\vdots$ & $\vdots$ & $\vdots$ & $\vdots$ & $\vdots$ & $\vdots$ & $\vdots$ & $\vdots$ & $\vdots$ & $\vdots$ \\
\hline 2014 & 6.38 & 6.20 & 6.03 & 5.92 & 5.92 & 6.21 & 6.20 & 6.39 & 6.43 & 6.37 & 6.31 & 6.26 \\
\hline 2015 & 6.11 & 6.07 & 6.07 & 6.12 & 6.26 & 6.35 & 6.79 & 6.96 & 6.91 & 6.79 & 6.7 & 6.7 \\
\hline
\end{tabular}

This article is consistent with the statistical yearbook, which defines breeding sows as sows who have given birth to one gilt and can continue to reproduce normally. Therefore, sows which are older than 8 months ${ }^{[35]}$ will become breeding sows after 114 days of gestation, that is, when they reach 12 months of age, they become breeding sows until being eliminated at the age of 54 months old after 3.5 years. So, to predict the total number of breeding sows for a month, we need to predict the number of breeding sows at the 12-54 month. This study is calculated from January 2000. New left gilts needed to take 53 months to grow to the 54 months old breeding sows. Therefore, the new left gilts in January 2000 would grow into 54 months old breeding sows in May 2004.Similarly, the new left gilts in February 2000 would grow into 54 months old breeding sows in May 2004. In other words, it is not until May 2004 that the number of breeding sows at all months of age can be predicted. According to the estimated value of the new left gilts and recursive model of pig population system, the number of breeding sows can be obtained from January 2004 to December 2015, as shown in Table 2.

According to the China Animal Husbandry and Veterinary Statistical Yearbook, the number of actual stock of breeding sows at the end of 2004 was 1.363 million. According to the relationship model between new left gilts and pork prices and the recursive model of pig population system, the estimated stock of breeding sows at the end of 2004 was 1.2873 million. The relative error from the actual statistics is $5.553392 \%$. The number of breeding sows in each month of December 2004 was corrected by the number of deviations, and the number of breeding sows in 
2004 was 1.363 million. If December 2004 is the base month of year, according to the recursive model of pig population system, the stocks of the breeding sows in the next month can be predicted and compared with the actual statistics. The calculation formulas of the relative error (RE) and the average relative error (ARE) are shown in Equations (45) and (46). The calculation results are shown in Table 3.

$$
\begin{gathered}
R E=\frac{|A V-P V|}{A V} \times 100 \% \\
A R E=\frac{\sum_{N=1}^{N} R E}{N}
\end{gathered}
$$

\begin{tabular}{|c|c|c|c|c|c|c|c|c|c|c|c|c|}
\hline & January & February & March & April & May & June & July & August & September & October & November & December \\
\hline 2004 & & & & & & 127.92 & 128.03 & 128.16 & 128.27 & 128.45 & 128.61 & 128.73 \\
\hline 2005 & 128.79 & 128.85 & 129.02 & 129.20 & 129.46 & 129.70 & 129.93 & 130.20 & 130.45 & 130.70 & 130.97 & 131.23 \\
\hline$\vdots$ & $\vdots$ & $\vdots$ & $\vdots$ & $\vdots$ & $\vdots$ & $\vdots$ & $\vdots$ & $\vdots$ & $\vdots$ & $\vdots$ & $\vdots$ & $\vdots$ \\
\hline 2014 & 156.02 & 156.15 & 156.11 & 156.08 & 156.16 & 156.38 & 156.76 & 157.25 & 157.72 & 158.18 & 158.60 & 158.71 \\
\hline 2015 & 158.64 & 158.43 & 158.12 & 157.74 & 157.60 & 157.52 & 157.57 & 157.64 & 157.63 & 157.58 & 157.25 & 156.73 \\
\hline
\end{tabular}

Table 2 Estimated value of breeding sows per month from 2004 to 2015

Table 3 Comparison table between the predicted and the actual value of the number of breeding sows in 2004-2015

\begin{tabular}{cccc}
\hline Year & $\begin{array}{c}\text { Predictive value } \\
\text { /ten thousand }\end{array}$ & $\begin{array}{c}\text { Actual value } \\
\text { /ten thousand }\end{array}$ & $\begin{array}{c}\text { Relative error } \\
/ \%\end{array}$ \\
\hline 2004 & 136.30 & 136.30 & \\
2005 & 131.23 & 145.30 & 9.68 \\
2006 & 132.54 & 131.21 & 1.01 \\
2007 & 132.99 & 121.70 & 9.28 \\
2008 & 139.16 & 121.70 & 14.34 \\
2009 & 145.63 & 134.00 & 8.68 \\
2010 & 148.04 & 135.10 & 9.58 \\
2011 & 148.99 & 132.40 & 12.53 \\
2012 & 152.64 & 140.20 & 8.87 \\
2013 & 155.67 & 142.00 & 9.63 \\
2014 & 158.71 & 140.91 & 12.63 \\
2015 & 156.73 & 134.60 & 16.44 \\
\hline
\end{tabular}

The average relative error between the predicted and the actual value of the prediction of breeding sows is $10.24 \%$. The average relative error is small, so the estimation method for the transfer of sows by month is reliable. This method can be used to predict the breeding sow population in the next month.

\subsubsection{Estimation of initial pig population state}

Based on the latest statistics of December 2015 as the base year, we forecast the supply of pork in Heilongjiang Province in the future. Before the prediction, we must verify the reliability of the method of the estimation of initial pig population state. According to this method, the initial state of the pig population was estimated.

(1) Verify the reliability of the initial state estimation method for the pig population. Take the estimation method of the initial state of the porker population as an example. According to the estimated value of the new left gilts in Heilongjiang Province from 2000 to 2015, the distribution of the number of pigs per month from 2006 to 2014 was estimated by the method of the estimation of initial pig population state. And making a comparison with the amount of slaughter pigs at the end of the year in The Statistical Yearbook of Chinese Animal Husbandry Veterinary. The analysis results are shown in Table 4.

The deviation and averaging are used to obtain an average relative error of $6.42 \%$ for the estimation of the number of finishing pigs. The deviation is small, so the estimation method for the transfer of sows by month is reliable. This method can be used to predict the porker population in the next month.

Table 4 Comparison table between the predicted and the actual value of the number of slaughter pigs in each year

\begin{tabular}{cccc}
\hline Year & $\begin{array}{c}\text { Predictive value } \\
\text { /ten thousand }\end{array}$ & $\begin{array}{c}\text { Actual value } \\
\text { /ten thousand }\end{array}$ & $\begin{array}{c}\text { Relative error } \\
/ \%\end{array}$ \\
\hline 2006 & 1391.90 & 1455.80 & 3.30 \\
2007 & 1401.10 & 1465.40 & 18.90 \\
2008 & 1401.60 & 1466.00 & 9.07 \\
2009 & 1477.90 & 1545.70 & 2.20 \\
2010 & 1542.90 & 1613.60 & 0.70 \\
2011 & 1563.00 & 1634.70 & 0.07 \\
2012 & 1574.80 & 1647.00 & 6.69 \\
2013 & 1616.20 & 1690.30 & 7.20 \\
2014 & 1648.70 & 1724.30 & 10.20 \\
2015 & 1677.30 & 1754.20 & 5.90 \\
\hline
\end{tabular}

(2) The initial state of the population is estimated, including the initial state of the new born piglet, the sow population, the boar population and the porker population. Due to the latest data of the current statistical yearbook to the breeding sows in 2015, this article takes December 2015 as the base year, and regards the number of pig populations as the initial state of the pigs' population in Heilongjiang Province, then the supply of pork in the future will be predicted. Based on the number of breeding sows in December 2015 and the initial state estimation model, it can be concluded that the number of new born piglets in December 2015 is shown in Table 5 .

Table 5 Number of new born piglets in December 2015

\begin{tabular}{cc}
\hline Age/month & Number/ten thousand \\
\hline 00 & 208.45 \\
0 & 187.61 \\
1 & 176.94 \\
\hline
\end{tabular}

From Table 4, it is concluded that the amount of breeding sows that were recursed in 2015 was 156.73 . By consulting the China Animal Husbandry and Veterinary Statistical Yearbook, The number of stock of breeding sows in 2015 was 1.346 million heads in the China Animal Husbandry and Veterinary Statistical Yearbook and the deviation is 0.16441 . The number of deviations was used to correct the amount of sows in each month of December 2015 , and the total number of breeding sows in 2015 was 134.6. The adjusted distribution of sows at each month is shown in Figure 5. 


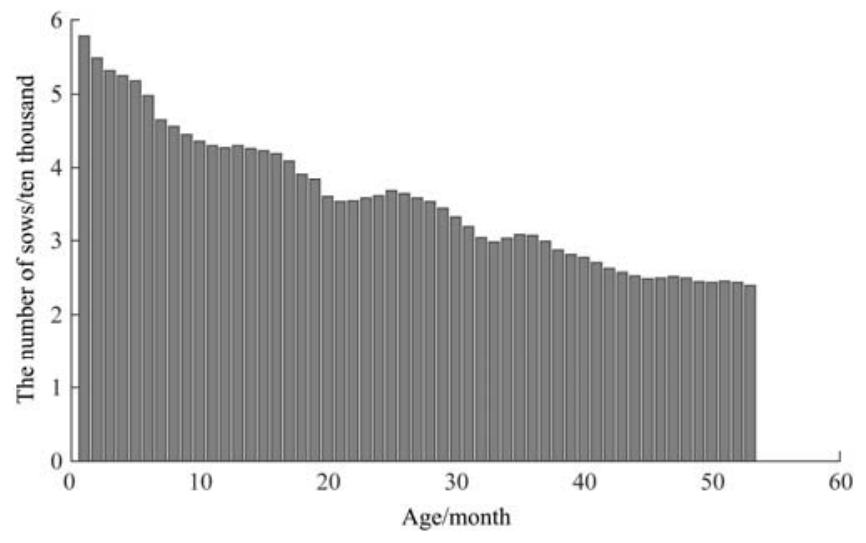

Figure 5 Distribution of sow population in December 2015

According to the breeding ratio of sows and boars, the distribution of boar populations in December 2015 was obtained, as shown in Figure 6.

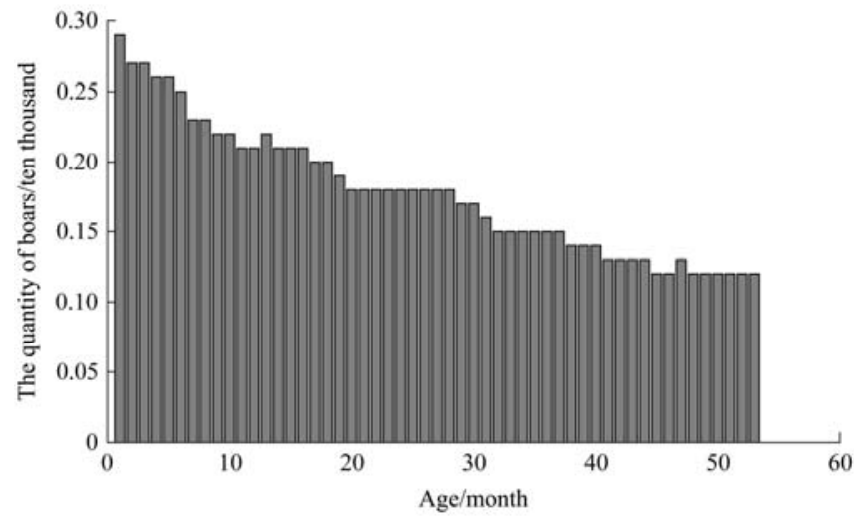

Figure 6 Distribution of boar populations in December 2015

Table 6 Distribution of finishing pigs in December 2015

\begin{tabular}{cc|cc}
\hline $\begin{array}{c}\text { Age } \\
\text { /month }\end{array}$ & $\begin{array}{c}\text { Number of pork pigs } \\
\text { /ten thousand }\end{array}$ & $\begin{array}{c}\text { Age } \\
\text { /month }\end{array}$ & $\begin{array}{c}\text { Number of pork pigs } \\
\text { /ten thousand }\end{array}$ \\
\hline 1 & 170.88 & 4 & 150.39 \\
2 & 161.74 & 5 & 147.03 \\
3 & 155.27 & 6 & 145.33 \\
\hline
\end{tabular}

3.3.3 Predict the distribution of pig population systems in Heilongiiang Province in the future

Firstly, the pork prices for each month of Heilongjiang Province in 2016-2018 are obtained, as shown in Table 7.

Table 7 Pork prices for each month from 2016 to 2018

\begin{tabular}{|c|c|c|c|c|c|}
\hline Time & $\begin{array}{c}\text { Price } \\
/ \text { yuan } \cdot \mathrm{kg}^{-1}\end{array}$ & Time & $\begin{array}{c}\text { Price } \\
\text { /yuan } \cdot \mathrm{kg}^{-1}\end{array}$ & Time & $\begin{array}{c}\text { Price } \\
\text { /yuan } \cdot \mathrm{kg}^{-1}\end{array}$ \\
\hline $\begin{array}{c}\text { January } \\
2016\end{array}$ & 26.14 & October 2016 & 25.51 & July 2017 & 21.83 \\
\hline $\begin{array}{c}\text { February } \\
2016\end{array}$ & 26.84 & $\begin{array}{c}\text { November } \\
2016\end{array}$ & 25.44 & August 2017 & 22.71 \\
\hline March 2016 & 26.55 & $\begin{array}{c}\text { December } \\
2016\end{array}$ & 26.34 & $\begin{array}{c}\text { September } \\
2017\end{array}$ & 22.73 \\
\hline April 2016 & 28.24 & January 2017 & 26.34 & October 2017 & 22.36 \\
\hline May 2016 & 29.37 & $\begin{array}{c}\text { February } \\
2017\end{array}$ & 25.59 & $\begin{array}{c}\text { November } \\
2017\end{array}$ & 22.19 \\
\hline June 2016 & 30.54 & March 2017 & 24.37 & $\begin{array}{c}\text { December } \\
2017\end{array}$ & 22.60 \\
\hline July 2016 & 29.74 & April 2017 & 23.59 & January 2018 & 22.22 \\
\hline August 2016 & 28.50 & May 2017 & 22.47 & February 2018 & 20.75 \\
\hline $\begin{array}{c}\text { September } \\
2016\end{array}$ & 27.54 & June 2017 & 21.53 & March 2018 & 18.07 \\
\hline
\end{tabular}

According to the future pork price data, the estimated model of the new left gilts for each month is used to calculate the number of new left gilts in the future, as shown in Table 8 .

Table 8 Number of new left gilts in each month in 2016-2018

\begin{tabular}{|c|c|c|c|c|c|}
\hline Time & $\begin{array}{c}\text { Number } \\
\text { /ten thousand }\end{array}$ & Time & $\begin{array}{c}\text { Number } \\
\text { /ten thousand }\end{array}$ & Time & $\begin{array}{c}\text { Number } \\
\text { /ten thousand }\end{array}$ \\
\hline $\begin{array}{c}\text { January } \\
2016\end{array}$ & 6.82 & $\begin{array}{l}\text { October } \\
2016\end{array}$ & 6.76 & July 2017 & 6.42 \\
\hline $\begin{array}{c}\text { February } \\
2016\end{array}$ & 6.88 & $\begin{array}{c}\text { November } \\
2016\end{array}$ & 6.75 & $\begin{array}{c}\text { August } \\
2017\end{array}$ & 6.50 \\
\hline $\begin{array}{l}\text { March } \\
2016\end{array}$ & 6.85 & $\begin{array}{c}\text { December } \\
2016\end{array}$ & 6.83 & \begin{tabular}{|c} 
September \\
2017
\end{tabular} & 6.50 \\
\hline April 2016 & 7.01 & $\begin{array}{c}\text { January } \\
2017\end{array}$ & 6.83 & $\begin{array}{c}\text { October } \\
2017\end{array}$ & 6.47 \\
\hline May 2016 & 7.12 & $\begin{array}{c}\text { February } \\
2017\end{array}$ & 6.77 & $\begin{array}{c}\text { November } \\
2017\end{array}$ & 6.45 \\
\hline June 2016 & 7.22 & March 2017 & 6.65 & \begin{tabular}{|l} 
December \\
2017
\end{tabular} & 6.49 \\
\hline July 2016 & 7.15 & April 2017 & 6.58 & $\begin{array}{c}\text { January } \\
2018\end{array}$ & 6.45 \\
\hline $\begin{array}{l}\text { August } \\
2016\end{array}$ & 7.04 & May 2017 & 6.48 & $\begin{array}{l}\text { February } \\
2018\end{array}$ & 6.32 \\
\hline $\begin{array}{l}\text { September } \\
2016\end{array}$ & 6.95 & June 2017 & 6.39 & $\begin{array}{l}\text { March } \\
2018\end{array}$ & 6.07 \\
\hline
\end{tabular}

Based on the initial state data of the pig population system in Heilongiiang Province in December 2015 and the data of the new left gilts, the recursive model of pig population system was used to obtain the number of breeding sows per month in 2016-2018.

Table 9 Number of breeding sows in each month in 2016-2018

\begin{tabular}{|c|c|c|c|c|c|}
\hline Time & $\begin{array}{c}\text { Number } \\
\text { /ten thousand }\end{array}$ & Time & $\begin{array}{c}\text { Number } \\
\text { /ten thousand }\end{array}$ & Time & $\begin{array}{c}\text { Number } \\
\text { /ten thousand }\end{array}$ \\
\hline $\begin{array}{c}\text { January } \\
2016\end{array}$ & 156.20 & $\begin{array}{l}\text { October } \\
2016\end{array}$ & 156.48 & July 2017 & 160.16 \\
\hline $\begin{array}{l}\text { February } \\
2016\end{array}$ & 155.69 & $\begin{array}{l}\text { November } \\
2016\end{array}$ & 156.76 & $\begin{array}{c}\text { August } \\
2017\end{array}$ & 160.55 \\
\hline $\begin{array}{l}\text { March } \\
2016\end{array}$ & 155.25 & \begin{tabular}{|l} 
December \\
2016
\end{tabular} & 157.12 & $\begin{array}{c}\text { September } \\
2017\end{array}$ & 160.86 \\
\hline April 2016 & 155.00 & $\begin{array}{c}\text { January } \\
2017\end{array}$ & 157.49 & $\begin{array}{c}\text { October } \\
2017\end{array}$ & 161.16 \\
\hline May 2016 & 154.87 & $\begin{array}{c}\text { February } \\
2017\end{array}$ & 157.82 & $\begin{array}{l}\text { November } \\
2017\end{array}$ & 161.45 \\
\hline June 2016 & 155.09 & $\begin{array}{l}\text { March } \\
2017\end{array}$ & 158.27 & $\begin{array}{l}\text { December } \\
2017\end{array}$ & 161.67 \\
\hline July 2016 & 155.47 & April 2017 & 158.79 & $\begin{array}{c}\text { January } \\
2018\end{array}$ & 161.79 \\
\hline $\begin{array}{l}\text { August } \\
2016\end{array}$ & 155.86 & May 2017 & 159.33 & $\begin{array}{l}\text { February } \\
2018\end{array}$ & 161.79 \\
\hline $\begin{array}{l}\text { September } \\
2016\end{array}$ & 156.20 & June 2017 & 159.78 & $\begin{array}{c}\text { March } \\
2018\end{array}$ & 161.73 \\
\hline
\end{tabular}

Since the initial state of the porker will be released after reaching the 6 months of age, the number of finishing pigs from January 2016 to May 2016 can be obtained according to the initial state of the porker population in December 2015. In addition, the ability to breeding sows in the initial state will breed new born piglets, and will experience new left gilts, boars and small pigs, and will be released at the end of June. In summary, we can get the number of slaughtered fattened hogs in each month from 2016 to 2018 by using the recursive model of pig population system.

The statistical bulletin of the National Economic and Social Development of Heilongjiang Province shows that the number of slaughtered fattened hogs in Heilongiiang Province in 2016 was 
18.447 million, and the number of slaughtered fattened hogs in 2017 was 19.032 million. According to Table 10, the predicted value of the number of slaughtered fattened hogs in 2016 is 18.01 million, with a relative error of $3.64 \%$, and the prediction accuracy is $96.36 \%$.and the value in 2017 is 18.563 million, with a relative error of $2.46 \%$, and the prediction accuracy is $97.54 \%$.

Table 10 Prediction of the number of slaughtered fattened hogs in each month in 2016-2018

\begin{tabular}{|c|c|c|c|c|c|}
\hline Time & $\begin{array}{c}\text { Number } \\
\text { /ten thousand }\end{array}$ & Time & $\begin{array}{c}\text { Number } \\
\text { /ten thousand }\end{array}$ & Time & $\begin{array}{c}\text { Number } \\
\text { /ten thousand }\end{array}$ \\
\hline $\begin{array}{c}\text { January } \\
2016\end{array}$ & 145.23 & $\begin{array}{l}\text { October } \\
2016\end{array}$ & 151.90 & July 2017 & 154.68 \\
\hline $\begin{array}{l}\text { February } \\
2016\end{array}$ & 145.35 & $\begin{array}{c}\text { November } \\
2016\end{array}$ & 151.67 & $\begin{array}{c}\text { August } \\
2017\end{array}$ & 155.12 \\
\hline $\begin{array}{l}\text { March } \\
2016\end{array}$ & 145.45 & $\begin{array}{c}\text { December } \\
2016\end{array}$ & 151.79 & $\begin{array}{c}\text { September } \\
2017\end{array}$ & 155.65 \\
\hline April 2016 & 145.45 & $\begin{array}{c}\text { January } \\
2017\end{array}$ & 152.36 & $\begin{array}{c}\text { October } \\
2017\end{array}$ & 156.28 \\
\hline May 2016 & 145.99 & $\begin{array}{c}\text { February } \\
2017\end{array}$ & 152.84 & $\begin{array}{c}\text { November } \\
2017\end{array}$ & 156.92 \\
\hline June 2016 & 160.61 & $\begin{array}{c}\text { March } \\
2017\end{array}$ & 153.36 & $\begin{array}{c}\text { December } \\
2017\end{array}$ & 157.35 \\
\hline July 2016 & 153.31 & April 2017 & 153.65 & $\begin{array}{c}\text { January } \\
2018\end{array}$ & 157.66 \\
\hline $\begin{array}{c}\text { August } \\
2016\end{array}$ & 152.73 & May 2017 & 153.86 & $\begin{array}{c}\text { February } \\
2018\end{array}$ & 158.06 \\
\hline $\begin{array}{l}\text { September } \\
2016\end{array}$ & 152.31 & June 2017 & 154.23 & $\begin{array}{l}\text { March } \\
2018\end{array}$ & 158.41 \\
\hline
\end{tabular}

The predicted value of the amount of slaughter pigs in each month of the Heilongjiang Province in Table 10 is multiplied by the average meat production amount of $78 \mathrm{~kg}$ per head of the meat pig equals the supply amount of pork for each month. Thus the predicted value of the pork supply amount for each month in 2016-2018 is shown in Table 11.

Table 11 Prediction of pork supply in each month of Heilongjiang Province from 2016 to 2018

\begin{tabular}{|c|c|c|c|c|c|}
\hline Time & $\begin{array}{l}\text { Number } \\
\text { /million } \mathrm{t}\end{array}$ & Time & $\begin{array}{l}\text { Number } \\
\text { /million } \mathrm{t}\end{array}$ & Time & $\begin{array}{l}\text { Number } \\
\text { /million } \mathrm{t}\end{array}$ \\
\hline $\begin{array}{c}\text { January } \\
2016\end{array}$ & 11.33 & $\begin{array}{c}\text { October } \\
2016\end{array}$ & 11.13 & July 2017 & 11.34 \\
\hline $\begin{array}{c}\text { February } \\
2016\end{array}$ & 11.34 & $\begin{array}{c}\text { November } \\
2016\end{array}$ & 11.12 & $\begin{array}{c}\text { August } \\
2017\end{array}$ & 11.37 \\
\hline $\begin{array}{c}\text { March } \\
2016\end{array}$ & 11.35 & $\begin{array}{c}\text { December } \\
2016\end{array}$ & 11.12 & $\begin{array}{c}\text { September } \\
2017\end{array}$ & 11.41 \\
\hline April 2016 & 11.35 & $\begin{array}{c}\text { January } \\
2017\end{array}$ & 11.17 & $\begin{array}{c}\text { October } \\
2017\end{array}$ & 11.45 \\
\hline May 2016 & 11.39 & $\begin{array}{c}\text { February } \\
2017\end{array}$ & 11.20 & $\begin{array}{c}\text { November } \\
2017\end{array}$ & 11.50 \\
\hline June 2016 & 11.90 & March 2017 & 11.24 & $\begin{array}{c}\text { December } \\
2017\end{array}$ & 11.53 \\
\hline July 2016 & 11.24 & April 2017 & 11.26 & $\begin{array}{c}\text { January } \\
2018\end{array}$ & 11.56 \\
\hline August 2016 & 11.19 & May 2017 & 11.28 & $\begin{array}{c}\text { February } \\
2018\end{array}$ & 11.58 \\
\hline $\begin{array}{l}\text { September } \\
2016\end{array}$ & 11.16 & June 2017 & 11.30 & March 2018 & 11.61 \\
\hline
\end{tabular}

The statistical bulletin of the national economic and social development in Heilongjiang Province shows that the supply of pork in Heilongjiang Province in 2016 was 138.2 million t, and the supply of pork in 2017 was 145 million t. According to Table 11, the predicted value of pork supply in 2016 is 135.5125 million t, the relative error is $1.92 \%$, and the prediction accuracy is $98.08 \%$. The predicted value of pork supply in 2017 is 136.0824 million $t$, the relative error is $6.18 \%$, and the prediction accuracy is $93.82 \%$. The relative error is small and the prediction accuracy is high.

3.3.4 Sensitivity analysis

Sensitivity analysis further evaluated the performance of the model and indicated the change in the quantity of pork supply of year 2017 due to variations in $D_{r}^{W}, \lambda, C R$ and $k$. Figure 4 illustrated the sensitivity test of each parameter in the pork supply prediction model. The model was found to be most sensitive to the level of incoming $\lambda$, followed by $D_{r}^{W}$ and then $C R$ as shown in Figure 6. In addition, the changes in $k$ value cannot cause changes in the quantity of pork supply. So the ratio of sows to boars was not sensitive to this model. As anticipated from Figure 7, the quantity of pork supply increases linearly with $\lambda$ and $C R$. and decreases with the increase of $D_{r}^{W}$. It implies that the model is more susceptible to changes in $\lambda$. Model sensitivity analysis indicated that how many litters per year was the main Influencing factors influencing the quantity of pork supply in the model.

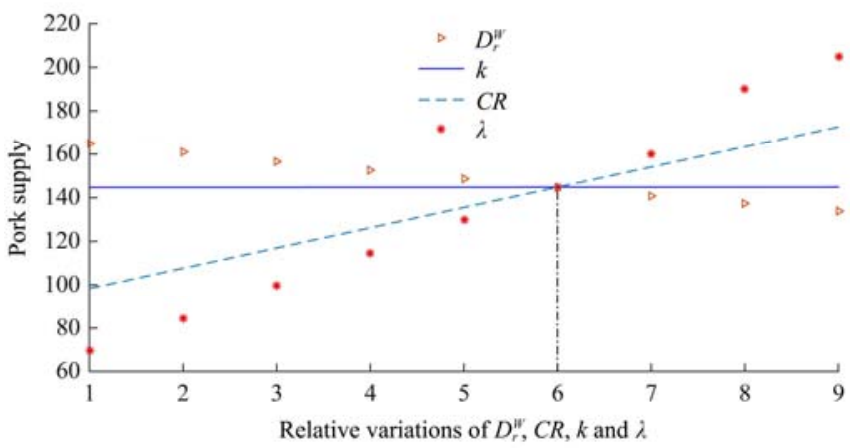

Note: The relative change of pork supply of year 2017 is plotted against the relative variations of $D_{r}^{W}, \lambda, C R$ and $k$.

Figure 7 Result of sensitivity analysis

\section{Conclusions}

Based on the population prediction model, the solution of pork supply prediction model was proposed via the calculation of pig population in this study. An example calculation was performed using pork supply in Heilongjiang Province of China as an example. The results showed that the prediction model of pork supply based on the population prediction model had small relative errors and high prediction accuracy. From the perspective of modeling, the prediction model of pork supply via the calculation of pig population based on the pig population system was an effective perspective to study the forecasting of pork supply. This prediction model can reflect the variation of pig population and pork supply every month in the future and has obvious advantages over the existing prediction models which can only predict the annual data.

In future research, it is proposed to evaluate the value of breeding mode of breeding sows, and to provide a system to monitor and control the number of pigs and pork in pig farm.

\section{Acknowledgements}

This research was supported by Heilongjiang Province Philosophy and Social Science Research Planning Project (18GLC205) (17GYB084); Heilongjiang Province Doctors Back Project (LBH-Z18024); Northeast Agricultural University Youth Talent Research Fund (18QC18).

The author is very grateful to three anonymous reviewers for invaluable comments on earlier versions of this article. 


\section{[References]}

[1] Ezekiel M. The cobweb theorem. Quarterly Journal of Economics, 1938; 52(2): 255-280.

[2] Kaldor N. A Classificatory note on the determinateness of equilibrium. Review of Economic Studies, 1934; 1(2): 122-136.

[3] Jaile-Benitez J M, Ferrer-Comalat J C, Linares-Mustarós S. Determining the influence variables in the pork price, based on expert systems. Scientific Methods for the Treatment of Uncertainty in Social Sciences. Springer, Cham, 2015: pp.81-92.

[4] Aydogdu M H. General analysis of recent changes in poultry meat consumptions in Turkey. International Journal of Advances in Agriculture Sciences, 2018; 12(3): 6-11

[5] Wu H, Qi Y, Chen D. A dynamic analysis of influencing factors in price fluctuation of live pigs-based on statistical data in Sichuan province, China. Asian Social Science, 2012; 8(7): 256.

[6] Jia W, Yang Y, Qin F. The study on China's pork industry chain price transmission mechanism: Based on province comparison. Statistics \& Information Forum, 2013; 3: 49-55.

[7] Zhou D, Yu X, Herzfeld T. Dynamic food demand in urban China. China Agricultural Economic Review, 2015; 7(1): 27-44.

[8] Xu S, Li Z, Cui L, Dong X, Kong F, Li G. Price transmission in China's swine industry with an application of MCM. Journal of Integrative Agriculture, 2012; 11(12): 2097-2106.

[9] Felipe I, Mól A, Almeida V. Application of ARIMA models in soybean series of prices in the north of Paraná. Custos e@ gronegócio Online, $2012 ; 8$.

[10] Adanacioglu H, Yercan M. An analysis of tomato prices at wholesale level in Turkey: An application of SARIMA model. Custos e@ gronegócio on line, 2012; 8(4): 52-75.

[11] Li G, Xu S, Li Z, Sun Y, Dong X. Using quantile regression approach to analyze price movements of agricultural products in china. Journal of Integrative Agriculture, 2012; 11(4): 674-683.

[12] Saengwong S, Jatuporn C, Roan S W. An analysis of Taiwanese livestock prices: empirical time series approaches. Journal of Animal and Veterinary Advances, 2012; 11(23): 4340-4346.

[13] Martín-Rodríguez G, Cáceres-Hernández J J. Forecasting pseudo-periodic seasonal patterns in agricultural prices. Agricultural Economics, 2012; 43(5): 531-544.

[14] Paul R K, Gurung B, Paul A. Modelling and forecasting of retail price of arhar dal in Karnal, Haryana. The Indian Journal of Agricultural Sciences, 2015; 85(1): 69-72.

[15] Wu L, Liu S, Yang Y. Grey double exponential smoothing model and its application on pig price forecasting in China. Applied Soft Computing, 2016; 39: 117-123.

[16] Tian F, Peng Y. Machine vision system of nondestructive real-time prediction of live-pig meat yield. Transactions of the CSAE, 2016; 32(2): 230-235. (in Chinese)

[17] Luo C G, Zhang M Z, Xue J L. Short-term forecasts of hog price based on ARIMA model, World Agriculture, 2010; 10: 45-48.

[18] Zheng L, Duan D, Lu F, Xu W, Yang C, Wang S. Integration forecast of Chinese pork consumption demand-Empirical based on ARIMA, VAR and VEC models. Systems Engineering-Theory \& Practice, 2013; 33(4):
918-925. (in Chinese)

[19] Zhang J H, Li Z M, Kong F T, Dong X X, Chen W, Wang S W. Prediction of pork prices based on SVM. Proceedings of 2013 World Agricultural Outlook Conference. Springer, Berlin, Heidelberg, 2014; pp.173-178.

[20] Ma Z, Chen Z, Chen T, et al. Application of machine learning methods in pork price forecast. Proceedings of the 2019 11th International Conference on Machine Learning and Computing. ACM, 2019; pp.133-136.

[21] Jurkėnaite N, Djuric I. Impact of the Russian trade bans on Lithuanian pork sector. Management Theory and Studies for Rural Business and Infrastructure Development, 2018; 40(4): 481-491

[22] Meng Z, Nan Z. Lean meat percentage prediction of pig carcass based on radial basis function neural network. Journal of Agricultural Mechanization Research, 2017; 6: 38. (in Chinese)

[23] Liu Y, Duan Q, Wang D, Zhang Z, Liu C. Prediction for hog prices based on similar sub-series search and support vector regression. Computers and Electronics in Agriculture, 2019; 157: 581-588.

[24] Shih M L, Huang B W, Chiu N H, Chiu C, Hu W Y. Farm price prediction using case-based reasoning approach - A case of broiler industry in Taiwan. Computers and electronics in agriculture, 2009; 66(1): 70-75.

[25] Ribeiro C O, Oliveira S M. A hybrid commodity price-Forecasting model applied to the sugar-alcohol sector. Australian Journal of Agricultural and Resource Economics, 2011; 55(2): 180-198.

[26] Jha G K, Sinha K. Time-delay neural networks for time series prediction: An application to the monthly wholesale price of oilseeds in India. Neural Computing and Applications, 2014; 24(3-4): 563-571.

[27] Su X, Wang Y, Duan S, Ma J et al. Detecting chaos from agricultural product price time series. Entropy, 2014; 16(12): 6415-6433.

[28] Pechrova M, Šimpach O. Modelling the development of the consumer price of sugar. Proceedings of the 35th International Conference Mathematical Methods in Economics (MME), 2017; pp.527-531.

[29] Wang B, Liu P, Zhang C, Wang J, Liu P. Prediction of garlic price based on ARIMA model. International Conference on Cloud Computing and Security. Springer, Cham, 2018; pp.731-739.

[30] Li Z M, Xu S W, Cui L G, Li G, Dong X, Wu J. The short-term forecas model of pork price based on CNN-GA. Advanced Materials Research. Trans Tech Publications, 2013; 628: 350-358.

[31] Liu T, Li Z, Teng G, Luo C. Prediction of pig weight based on radical basis function neural network. Journal of agricultural machinery, 2013; 44(8): 245-249.

[32] Tao X, Chongguang L I, Yukun B. An improved EEMD-based hybrid approach for the short-term forecasting of hog price in China. Agricultural Economics, 2017; 63(3): 136-148.

[33] Song J. Population prediction and population control. People's Publishing House, 1982. (in Chinese)

[34] Harlow A A. The hog cycle and the cobweb theorem. Journal of Farm Economics, 1960; 42(4): 842-853.

[35] Ministry of Agriculture and Rural Affairs in China. Technical specifications for ear tags for breeding sows. http://www.moa.gov.cn/nybgb/2010/dyq/201805/t20180529_6145222.htm. (in Chinese) 